\title{
Analisis Kesiapan Blended Learning Di Lingkungan Program Studi Teknik Informatika Universitas PGRI Madiun
}

\author{
Slamet Riyanto ${ }^{1}$, Hani Atun Mumtahana ${ }^{2}$ \\ 1,2Universitas PGRI Madiun \\ 1,2Jl. Setiabudi No. 85 Madiun, Indonesia \\ 1'selamat@unipma.ac.id, 2hany_alea03@yahoo.com
}

\begin{abstract}
The purpose of this study was to determine the level of preparedness of blended learning in the Informatics Engineering Study Program Environment at the PGRI Madiun University. This study uses a survey research approach with a total sample of 195 people. The research instrument used questionnaires with Likert scale. Data analysis in this study uses descriptive analysis with learning readiness approach adopted from Aydin and Tasci. The result of the research shows that the readiness of blended learning in informatics engineering study program of PGRI Madiun University, for personal factor or dimension is assessed Not ready needs some works. Self-development factors or dimensions are assessed Not ready needs some works. Factors or dimensions of technology are assessed Ready but needs a few improvement. Factors or dimensions of innovation are rated Not ready needs some works.
\end{abstract}

Keywords: ELR readiness; blended learning; learning innovation

\begin{abstract}
Abstrak
Tujuan penelitian ini adalah untuk mengetahui tingkat kesiapan blended learning di Lingkungan Program Studi Teknik Informatika Universitas PGRI Madiun. Penelitian ini menggunakan pendekatan penelitian survei dengan jumlah sampel penelitian ini sebanyak 195 orang. Instrumen penelitian yang menggunakan kuesioner dengan skala Likert. Analisis data pada penelitian ini menggunakan analisis deskriptif dengan pendekatan kesiapan learning yang diadopsi dari Aydin dan Tasci. Hasil penelitian menunjukkan bahwa kesiapan blended learning yang ada di program studi Teknik Informatika Universitas PGRI Madiun, untuk faktor atau dimensi personal dinilai Not ready needs some works. Faktor atau dimensi selfdevelopment dinilai Not ready needs some works. Faktor atau dimensi technology dinilai Ready but needs a few improvement. Faktor atau dimensi innovation dinilai Not ready needs some works.
\end{abstract}

Kata kunci: kesiapan ELR; blended learning; inovasi pembelajaran

\section{PENDAHULUAN}

Inovasi pembelajaran harus selalu dimiliki oleh para dosen dalam melakukan kegiatan belajara mengajar. Terlebih lagi, metode pembelajaran di perguruan tinggi tentunya berbeda dengan pembelajaran di tingkat sekolah menengah. Dosen harus memiliki daya kreasi dan inovasi yang tinggi untuk memacu dan memotivasi mahasiswa dalam kegiatan belajar. Inovasi pembelajaran juga menjadi masalah di lingkungan program studi Teknik Informatika Universitas PGRI Madiun. Para dosen masih menerapkan model pembelajaran konvensional dengan metode tatap muka $12-14$ kali pertemuan. Metode ini dinilai kurang efektif karena mahasiswa kurang memiliki daya kreativitas dalam mengembangkan ilmu yang dipelajarinya. Selain itu, metode konvensional menjadikan mahasiswa kurang berkembang 
dalam belajar, mahasiswa sering mengandalkan materi yang diberikan dosen tanpa mau membaca dan mencari materi sendiri di luar jam kuliah.

Permasalahan terkait proses pembelajaran ini apabila berlangsung terus menerus akan menjadikan mahasiswa dan dosen kurang efektif dalam belajar, maka perlu adanya inovasi yang tepat dalam pelaksanaan pembelajaran khususnya bagi program studi Teknik Informatika. Salah satu solusi yang ditawarkan adalah menerapkan pembelajaran blended learning, yaitu menerapkan pembelajaran konvensional dengan tatap muka dan pembelajaran berbasis online. Pembelajaran blended learning ini pernah diujicoba pada mata kuliah statistik berbasis praktikum dengan aplikasi software SPSS. Hasil pembelajaran blended learning mendapat respon positif dari mahasiswa dan mampu meningkatkan pemahaman mahasiswa terhadap pelajaran statistik yang dianggap sulit oleh mahasiswa.

Berdasarkan pengalaman pelaksanaan pembelajaran berbasis blended learning tersebut, maka model pembelajaran ini dapat dijadikan acuan untuk menerapkan pembelajaran yang efektif dan efisien untuk sebagian besar mata kuliah di lingkungan program studi Teknik Informatika. Untuk menerapkan model pembelajaran ini, maka terlebih dahulu harus diketahui kesiapan pembelajaran blended learning yang ada di lingkungan Teknik Informatika. Pengukuran kesiapan blended learning ini sangat diperlukan guna mengetahui strategi yang diambil dalam proses pembelajaran blended learning. Penelitian terkait kesiapan pembelajaran blended learning ini juga mengacu pada hasil penelitian yang dilakukan oleh Riyanto dan Nugrahanti, dimana temuan penelitian menunjukkan bahwa pembelajaran statistik berbasis praktikum dengan bantuan software SPSS harus didukung pembelajaran multimedia guna mempermudah pemahaman mahasiswa[1]. Lebih lanjut, dijelaskan bahwa pembelajaran statistik dapat dikembangkan melalui e-learning, salah satunya dengan aplikasi moodle. Pembelajaran statistik berbasis praktikum dengan aplikasi software SPSS ini menerapkan metode blended learning dengan komposisi $60 \%$ teori dengan tatap muka dan $40 \%$ e-learning. Dari hasil penelitian diketahui bahwa ada perbedaan tingkat motivasi belajar antara kelas yang diterapkan metode blended learning dengan metode konvensional[2].

Untuk mengetahui kesiapan teknologi dalam pembelajaran blended learning, maka penelitian ini juga mereferensi dari hasil penelitian Napitupulu, bahwa pada model ELR Chapnick menunjukkan bahwa ada delapan faktor yang mempengaruhi kesiapan e-learning, yaitu psychological readiness, sociological readiness, environmental readiness, technological skill readiness, content readiness, human resource readiness, financial readiness, equipment readiness, Innovation readiness dan institution readiness[3]. Penelitian Fariani, untuk mengukur kesiapan e-learning berdasarkan 6 faktor yaitu: Sumber Daya Manusia (SDM), organisasi, teknologi, keadaan keuangan organisasi, infrastruktur, isi materi[4]. Penelitian Juwindar, mengukur kesiapan e-learning berdasarkan empat faktor, yaitu: faktor karakteristik personal, kesiapan budaya, kesiapan teknologi dan kesiapan isi atau materi[5]. Penelitian Seta, dkk, mengukur kesiapan e-learning berdasarkan 
lima faktor utama, yaitu: teknologi, sumber daya manusia, organisasi, pembiayaan dan materi[6]. Penelitian Aydin dan Tasci, mengukur kesiapan e-learning berdasarkan empat faktor utama, yaitu: teknologi, inovasi, pribadi, pengembangan diri[7]. Berdasarkan uraian penelitian terdahulu, maka diketahui bahwa penelitian kesiapan blended learning ini menggunakan pendekatan dari hasil penelitian Aydin dan Tasci. Gap research penelitian ini terletak dari instrumen atau indikator yang digunakan, dimana pada penelitian Aydin dan Tasci condong pada kesiapan e-learning di dunia industri, sedangkan penelitian ini lebih fokus di bidang pendidikan sehingga indikator atau instrumen pengukuran mengalami perubahan yang disesuaikan dengan objek penelitian.

\section{METODOLOGI PENELITIAN}

\subsection{Kesiapan Blended Learning}

Kesiapan pembelajaran Blended Learning menggambarkan seberapa siap suatu organisasi dalam beberapa aspek untuk mengimplementasikan pembelajaran tata muka dan e-learning. Kesiapan tidak hanya terhadap pengajar atau siswa melainkan kesiapan organisasi itu sendiri. Untuk mengukur kesiapan blended learning digunakan model dari Aydin dan Tasci, yang menyebutkan ada empat faktor kesiapan e-learning, yaitu: 1 . Faktor teknologi, yaitu mempertimbangkan cara untuk mengefektifkan pemanfaatan teknologi yaitu e-learning di lingkungan sekolah); 2. Faktor inovasi, yaitu mempertimbangkan pengalaman dari sumber daya manusia dalam inovasi pembelajaran menggunakan teknologi; 3. Faktor manusia, yaitu mempertimbangkan karakteristik dari sumber daya manusia dalam proses pembekajaran; 4. Faktor pengembangan diri, yaitu mempertimbangkan kemampuan organisasi dalam penerapan e-learning [7].

\subsection{Kerangka Penelitian}

Kerangkan penelitian ini akan menjelaskan keterkaitan antara teori yang digunakan dengan kajian empiris yang menjadi acuan pada penelitian ini. Selain itu, kerangka penelitian ini juga dapat menjelaskan konsep atau model penelitian yang digunakan. Berikut gambar kerangka penelitian ini:

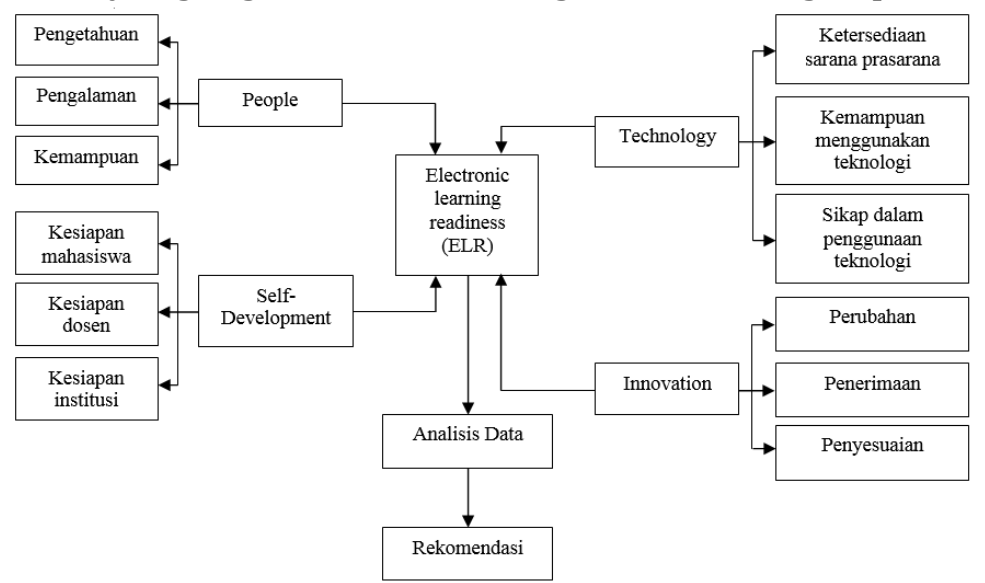

Gambar 1. Kerangka Penelitian Kesiapan Pembelajaran Blended Learning 
Penelitian ini menggunakan pendekatan penelitian survei dengan menggunakan instrumen penelitian berupa kuesioner. Populasi penelitian ini adalah seluruh mahasiswa, dosen dan tenaga kependidikan yang berjumlah 379 orang. Penghitungan sampel penelitian ini menggunakan pendekatan rumus Slovin sebagai berikut:

$n=\frac{N}{1+N e^{2}}$

Dimana

$\mathrm{n} \quad=$ jumlah sampel minimal

$\mathrm{N} \quad=$ jumlah populasi penelitian yang berjumlah 379 orang

e = standart error pengambilan sampel dan ditetapkan $5 \%$.

maka perhitungan sampel penelitian ini adalah

$n=\frac{379}{1+379(0,05)^{2}}$

$n=\frac{379}{1+379(0,0025)}$

$n=\frac{379}{1+0,948}$

$n=\frac{379}{1,948}=194,6$

Berdasarkan hasil penghitungan sampel di atas, maka diperoleh sampel penelitian ini sebanyak 195 orang. Instrumen penelitian yang menggunakan kuesioner dengan pendekatan skala Likert. Kuesioner didesain dengan pendekatan model integrasi ELR yang diadopsi dari hasil penelitian Aydin dan Tasci (2005) dengan mengambil 4 (empat) dimensi atau faktor $e$ learning readiness. Skala Likert yang digunakan terdiri dari 5 skala pengukuran yaitu mulai dari sangat tidak setuju sampai dengan sangat setuju. Analisis data pada penelitian ini menggunakan analisis deskriptif dengan pendekatan kesiapan learning yang diadopsi dari Aydin dan Tasci (2005) dengan rentang skala sebagai berikut:

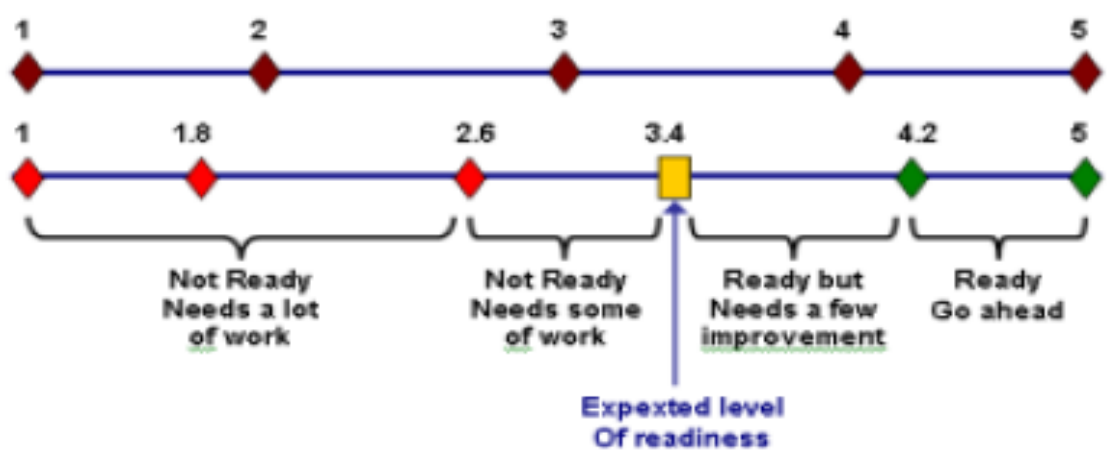

Gambar 2. Rentang Skala Penilaian Model Aydin dan Tasci

Rentang skala Aydin dan Tasci (2005) memberikan informasi bahwa skor rata-rata 3.40 merupakan skor minimal untuk tingkat kesiapan penerapan e-learning baik untuk skor rata-rata masing-masing item pernyataan ataupun skor rata-rata total dari masing-masing faktor. 


\section{HASIL DAN PEMBAHASAN}

Hasil uji validitas dan reliabilitas instrumen penelitian bertujuan untuk mengetahui kualitas dan keabsahan data penelitian. Dari hasil analisis data diperoleh hasil uji validitas sebagai berikut:

Tabel 1. Hasil Uji Validitas dan Reliabilitas Instrumen Penelitian

\begin{tabular}{|c|c|c|c|c|c|}
\hline Faktor & $\begin{array}{c}\text { Item } \\
\text { Pernyataan }\end{array}$ & $\begin{array}{l}\text { Nilai Corrected } \\
\text { Item-Total } \\
\text { Correlation } \\
\end{array}$ & Ket. & $\begin{array}{c}\text { Nilai } \\
\text { Cronbach's } \\
\text { Alpha } \\
\end{array}$ & Ket. \\
\hline \multirow{7}{*}{ Personal } & F1_1 & 0.472 & Valid & \multirow{7}{*}{0.816} & \multirow{7}{*}{ Reliabel } \\
\hline & F1_2 & 0.601 & Valid & & \\
\hline & F1_3 & 0.677 & Valid & & \\
\hline & F1_4 & 0.528 & Valid & & \\
\hline & F1_5 & 0.553 & Valid & & \\
\hline & F1_6 & 0.610 & Valid & & \\
\hline & F1_7 & 0.436 & Valid & & \\
\hline \multirow{6}{*}{$\begin{array}{c}\text { Self- } \\
\text { Development }\end{array}$} & F2_1 & 0.315 & Valid & \multirow{6}{*}{0.745} & \multirow{6}{*}{ Reliabel } \\
\hline & $\mathrm{F} 2 \_2$ & 0.444 & Valid & & \\
\hline & F2_3 & 0.370 & Valid & & \\
\hline & F2_4 & 0.615 & Valid & & \\
\hline & F2_5 & 0.542 & Valid & & \\
\hline & F2_6 & 0.642 & Valid & & \\
\hline \multirow{8}{*}{ Technology } & F3_1 & 0.638 & Valid & \multirow{8}{*}{0.876} & \multirow{8}{*}{ Reliabel } \\
\hline & F3_2 & 0.648 & Valid & & \\
\hline & F3_3 & 0.684 & Valid & & \\
\hline & F3_4 & 0.694 & Valid & & \\
\hline & F3_5 & 0.708 & Valid & & \\
\hline & F3_6 & 0.560 & Valid & & \\
\hline & F3_7 & 0.649 & Valid & & \\
\hline & F3_8 & 0.511 & Valid & & \\
\hline \multirow{6}{*}{ Innovation } & F4_1 & 0.555 & Valid & \multirow{6}{*}{0.756} & \multirow{6}{*}{ Reliabel } \\
\hline & F4_2 & 0.514 & Valid & & \\
\hline & F4_3 & 0.357 & Valid & & \\
\hline & F4_4 & 0.488 & Valid & & \\
\hline & F4_5 & 0.628 & Valid & & \\
\hline & F4_6 & 0.669 & Valid & & \\
\hline
\end{tabular}

Berdasarkan Tabel 1 di atas menunjukkan bahwa hasil uji validitas dari semua item pernyataan memiliki nilai Corrected Item-Total Correlation lebih besar dari $r$ tabel $(\mathrm{df}=\mathrm{n}-2 ; \alpha=0,5) ;(\mathrm{df}=195-2 ; \alpha=0,5)=0,1406$; artinya bahwa item pernyataan dari masing-masing faktor yang menentukan kesiapan learning dinyatakan valid. Uji reliabilitas dari masing-masing faktor juga memiliki nilai Cronbach's Alpha lebih besar dari 0,7; sehingga keempat faktor pembentuk kesiapan learning dinyatakan reliabel atau handal. Setelah dilakukan uji validitas dan reliabilitas, maka langkah selanjutnya adalah melakukan analisis deskriptif dengan pendekatan analisis kesiapan learning yang diadopsi dari Aydin dan Tasci (2005), sebagai berikut:

Tabel 2. Hasil Analisis Deskriptif

\begin{tabular}{cllcc}
\hline Faktor & \multicolumn{2}{c}{ Item pernyataan kuesioner } & Skor Mean & Keterangan \\
\hline \multirow{3}{*}{ Personal } & $\begin{array}{l}\text { Mahasiswa telah mengetahui metode } \\
\text { pembelajaran berbasis Blended Learning }\end{array}$ & 3.2051 & $\begin{array}{c}\text { Not ready needs } \\
\text { some works }\end{array}$ \\
\cline { 2 - 4 } & $\begin{array}{l}\text { Di setiap kelas terdapat mahasiswa yang memiliki } \\
\text { pemahaman yang menonjol dalam pelaksanaan }\end{array}$ & 3.3641 & $\begin{array}{c}\text { Not ready needs } \\
\text { some works }\end{array}$ \\
\hline
\end{tabular}


Jurnal Sains Komputer \& Informatika (J-SAKTI)

Volume (2) No.2 September 2018, pp. 191-199

ISSN:2548-9771/EISSN:2549-7200

http://tunasbangsa.ac.id/ejurnal/index.php/jsakti

\begin{tabular}{|c|c|c|c|}
\hline Faktor & Item pernyataan kuesioner & Skor Mean & Keterangan \\
\hline & pembelajaran berbasis Blended Learning & & \\
\hline & $\begin{array}{l}\text { Di setiap kelas terdapat mahasiswa yang memiliki } \\
\text { inisiatif dalam pengembangan pembelajaran } \\
\text { berbasis Blended Learning }\end{array}$ & 3.3897 & $\begin{array}{l}\text { Not ready needs } \\
\text { some works }\end{array}$ \\
\hline & 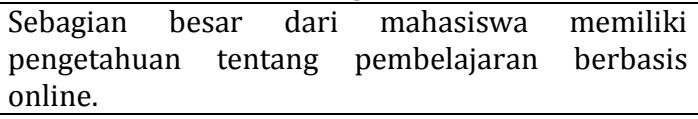 & 3.6462 & $\begin{array}{l}\text { Ready but needs } \\
\text { a few } \\
\text { improvement }\end{array}$ \\
\hline & $\begin{array}{l}\text { Di setiap kelas ada beberapa mahasiswa yang } \\
\text { pernah mengikuti kegiatan pelatihan untuk } \\
\text { pembelajaran berbasis online }\end{array}$ & 3.4974 & $\begin{array}{l}\text { Ready but needs } \\
\text { a few } \\
\text { improvement }\end{array}$ \\
\hline & $\begin{array}{l}\text { Program Studi ini memiliki pakar e-learning yang } \\
\text { memadai atau yang spesialis seperti ahli konten, } \\
\text { ahli desain website, pemrogram komputer yang } \\
\text { akan menolong mahasiswa dan dosen untuk } \\
\text { melaksanakan sebuah pembelajaran berbasis } \\
\text { Blended Learning }\end{array}$ & 3.3487 & $\begin{array}{l}\text { Not ready needs } \\
\text { some works }\end{array}$ \\
\hline & $\begin{array}{l}\text { Dosen memiliki kemampuan untuk menciptakan } \\
\text { pembelajaran yang kreatif dan inovatif }\end{array}$ & 3.3179 & $\begin{array}{l}\text { Not ready needs } \\
\text { some works }\end{array}$ \\
\hline & Skor rata-rata total & 3.3956 & $\begin{array}{l}\text { Not ready needs } \\
\text { some works }\end{array}$ \\
\hline \multirow{7}{*}{ Self-Development } & $\begin{array}{l}\text { Secara sukarela, mahasiswa mau bergabung dalam } \\
\text { kelompok belajar Blended Learning yang dibentuk } \\
\text { dosen }\end{array}$ & 3.4103 & $\begin{array}{c}\text { Ready but needs } \\
\text { a few } \\
\text { improvement } \\
\end{array}$ \\
\hline & $\begin{array}{l}\text { Mahasiswa menghabiskan beberapa waktu }(15,30 \\
\text { atau } 60 \text { menit) untuk belajar melalui e-learning di } \\
\text { setiap waktunya (pagi, sore, malam, atau malam } \\
\text { hari) }\end{array}$ & 3.2718 & $\begin{array}{l}\text { Not ready needs } \\
\text { some works }\end{array}$ \\
\hline & $\begin{array}{l}\text { Kepala Program Studi mendorong dosen dan } \\
\text { mahasiswa untuk melakukan proses pembelajaran } \\
\text { berbasis Blended Learning }\end{array}$ & 3.3436 & $\begin{array}{l}\text { Not ready needs } \\
\text { some works }\end{array}$ \\
\hline & $\begin{array}{l}\text { Menurut mahasiswa, pembelajaran berbasis } \\
\text { Blended Learning layak diterapkan bagi setiap } \\
\text { dosen }\end{array}$ & 3.3846 & $\begin{array}{l}\text { Not ready needs } \\
\text { some works }\end{array}$ \\
\hline & $\begin{array}{l}\text { Menurut mahasiswa, Program Studi siap untuk } \\
\text { pelaksanaan pembelajaran berbasis Blended } \\
\text { Learning }\end{array}$ & 3.3231 & $\begin{array}{l}\text { Not ready needs } \\
\text { some works }\end{array}$ \\
\hline & $\begin{array}{l}\text { Menurut mahasiswa, dosen siap untuk } \\
\text { pelaksanaan pembelajaran berbasis Blended } \\
\text { Learning }\end{array}$ & 3.3692 & $\begin{array}{l}\text { Not ready needs } \\
\text { some works }\end{array}$ \\
\hline & Skor rata-rata total & 3.3504 & \\
\hline \multirow{7}{*}{ Technology } & $\begin{array}{l}\text { Mahasiswa memiliki akses komputer untuk } \\
\text { digunakan secara individu }\end{array}$ & 3.4051 & $\begin{array}{l}\text { Ready but needs } \\
\quad \text { a few } \\
\text { improvement }\end{array}$ \\
\hline & $\begin{array}{l}\text { Mahasiswa memiliki akses internet untuk } \\
\text { digunakan dalam e-learning }\end{array}$ & 3.4154 & $\begin{array}{l}\text { Ready but needs } \\
\text { a few } \\
\text { improvement }\end{array}$ \\
\hline & $\begin{array}{l}\text { Mahasiswa dapat mengakses internet/intranet di } \\
\text { luar dari area kampus (di rumah, di café ,dll) }\end{array}$ & 3.5333 & $\begin{array}{l}\text { Ready but needs } \\
\text { a few } \\
\text { improvement }\end{array}$ \\
\hline & $\begin{array}{l}\text { Mahasiswa memiliki kemampuan dasar komputer } \\
\text { (seperti keyboarding, menggunakan mouse, } \\
\text { mengedit file, menyimpan, membuat file, dsb) }\end{array}$ & 3.5795 & $\begin{array}{l}\text { Ready but needs } \\
\text { a few } \\
\text { improvement }\end{array}$ \\
\hline & $\begin{array}{l}\text { Mahasiswa memiliki kemampuan dasar internet } \\
\text { (seperti email, chat, browsing dsb) }\end{array}$ & 3.6513 & $\begin{array}{l}\text { Ready but needs } \\
\text { a few } \\
\text { improvement }\end{array}$ \\
\hline & $\begin{array}{l}\text { Mahasiswa dapat membaca dan mengerti serta } \\
\text { mengikuti berbagai instruksi /perintah di dalam e- } \\
\text { learning untuk menyelesaikan suatu tugas }\end{array}$ & 3.4256 & $\begin{array}{l}\text { Ready but needs } \\
\text { a few } \\
\text { improvement }\end{array}$ \\
\hline & Mahasiswa terbiasa menggunakan teknologi & 3.4359 & Ready but needs \\
\hline
\end{tabular}


Jurnal Sains Komputer \& Informatika (J-SAKTI)

Volume (2) No.2 September 2018, pp. 191-199

ISSN:2548-9771/EISSN:2549-7200

http://tunasbangsa.ac.id/ejurnal/index.php/jsakti

\begin{tabular}{|c|c|c|c|}
\hline Faktor & Item pernyataan kuesioner & Skor Mean & Keterangan \\
\hline & komputer dalam mengerjakan tugas kuliah & & $\begin{array}{c}\text { a few } \\
\text { improvement }\end{array}$ \\
\hline & $\begin{array}{l}\text { Dosen memiliki kecakapan dalam menggunakan } \\
\text { teknologi komputer dalam pembelajaran Blended } \\
\text { Learning }\end{array}$ & 3.2974 & \\
\hline & Skor rata-rata total & 3.4679 & $\begin{array}{l}\text { Ready but needs } \\
\text { a few } \\
\text { improvement }\end{array}$ \\
\hline \multirow{7}{*}{ Innovation } & $\begin{array}{l}\text { Sebagian besar mahasiswa mau menerima inovasi } \\
\text { teknologi pembelajaran berbasis online }\end{array}$ & 3.4051 & $\begin{array}{l}\text { Ready but needs } \\
\quad \text { a few } \\
\text { improvement }\end{array}$ \\
\hline & $\begin{array}{lccr}\text { Mahasiswa } & \text { merasakan } & \text { adanya } & \text { perubahan } \\
\text { penggunaan } & \text { teknologi } & \text { untuk } & \text { kegiatan } \\
\text { pembelajaran berbasis } & \text { Blended Learning } & \\
\end{array}$ & 3.4154 & $\begin{array}{l}\text { Ready but needs } \\
\text { a few } \\
\text { improvement }\end{array}$ \\
\hline & $\begin{array}{l}\text { Universitas telah memasang beberapa peralatan } \\
\text { teknologi untuk pelaksanaan pembelajaran } \\
\text { berbasis Blended Learning }\end{array}$ & 3.0154 & $\begin{array}{l}\text { Not ready needs } \\
\text { some works }\end{array}$ \\
\hline & $\begin{array}{lrrr}\text { Mahasiswa } & \text { menerima } & \text { perubahan } & \text { dalam } \\
\text { pembelajaran berbasis } & \text { Blended } & \text { Learning } \\
\text { (perkuliahan lebih efektif) } & & \\
\end{array}$ & 3.3795 & $\begin{array}{l}\text { Not ready needs } \\
\text { some works }\end{array}$ \\
\hline & $\begin{array}{l}\text { Mahasiswa mampu menyesuaikan perubahan } \\
\text { perkuliahan dari konvensional Blended Learning } \\
\text { dengan mudah }\end{array}$ & 3.3333 & $\begin{array}{l}\text { Not ready needs } \\
\text { some works }\end{array}$ \\
\hline & $\begin{array}{l}\text { Dosen mampu menyesuaikan perubahan } \\
\text { perkuliahan dari konvensional Blended Learning } \\
\text { dengan mudah }\end{array}$ & 3.3026 & $\begin{array}{l}\text { Not ready needs } \\
\text { some works }\end{array}$ \\
\hline & Skor rata-rata total & 3.3086 & $\begin{array}{c}\text { Not ready needs } \\
\text { some works }\end{array}$ \\
\hline
\end{tabular}

Dari hasil Tabel 2 di atas dapat dibuat radar chart untuk mengetahui faktor kesiapan yang paling siap hingga paling tidak siap sebagai berikut:

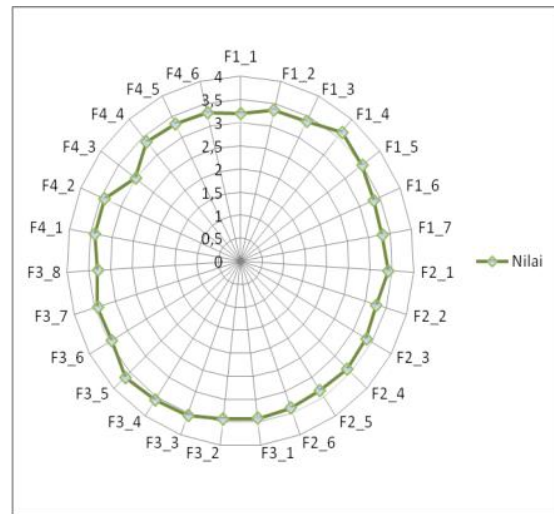

Gambar 3. Radar Chart Kesiapan Blended Learning

Terkait dengan kesiapan blended learning yang ada di program studi Teknik Informatika Universitas PGRI Madiun, dapat dijelaskan bahwa faktor atau dimensi personal memiliki skor rata-rata sebesar 3,3956 yang artinya Not ready needs some works. Faktor atau dimensi self-development memiliki skor rata-rata sebesar 3,3504 yang artinya Not ready needs some works. Faktor atau dimensi technology memiliki skor rata-rata sebesar 3,4679 yang artinya Ready but needs a few improvement. Faktor atau dimensi innovation 
memiliki skor rata-rata sebesar 3,3086 yang artinya Not ready needs some works.

\section{SIMPULAN}

Berdasarkan hasil analisis dan pembahasan pada penelitian ini dapat disimpulkan bahwa dari empat faktor atau dimensi tersebut diketahui bahwa hanya faktor atau dimensi technology yang memiliki kesiapan dan masih dibutuhkan beberapa perbaikan. Untuk faktor atau dimensi personal, SelfDevelopment dan innovation dinilai tidak siap dan dibutuhkan beberapa penambahan. Berdasarkan kesimpulan di atas, maka penelitian ini memberikan rekomendasi dalam pelaksanaan pembelajaran blended learning sebagai berikut:

a. Pengajar perlu melakukan sosialisasi metode pembelajaran berbasis Blended Learning, sehingga mahasiswa mengetahui model dan strategi pembelajaran tersebut.

b. Mahasiswa harus dibiasakan untuk mau mengakses atau menghabiskan beberapa waktu untuk belajar melalui e-learning secara rutin dalam mengerjakan tugas kuliah.

c. Institusi perlu melakukan pelatihan untuk meningkatkan kompetensi dosen dalam menggunakan teknologi komputer dalam pembelajaran Blended Learning.

d. Institusi diharapkan memberikan fasilitas penunjang dengan cara memasang beberapa peralatan teknologi di kampus untuk pelaksanaan pembelajaran berbasis Blended Learning.

\section{DAFTAR PUSTAKA}

[1] Riyanto, Slamet dan Nugrahanti, Fatim. 2018. Pengembangan Pembelajaran Statistika Berbasis Praktikum Aplikasi Software SPSS dengan Bantuan Multimedia untuk Mempermudah Pemahaman Mahasiswa terhadap Ilmu Statistika.

[2] . 2018. Perancangan Aplikasi Moodle untuk Pembelajaran Statistika Berbasis Praktikum Aplikasi Software SPSS dengan Bantuan Multimedia.

[3] Napitupulu, Darmawan. 2016. Kesiapan Implementasi Sistem ELearning Di Lingkungan Universitas XYZ. Seminar Nasional Technopreneurship dan Alih Teknologi 2016. Pusat Inovasi - LIPI. Hal. 64-75.

[4] Fariani, Rida Indah. 2013. Pengukuran Tingkat Kesiapan E-Learning (ELearning Readiness) Studi Kasus pada Perguruan Tinggi ABC di Jakarta. Seminar Nasional Aplikasi Teknologi Informasi (SNATI) 2013 Yogyakarta, 15 Juni 2013. ISSN: 1907 - 5022. Hal. G-1-G-7.

[5] Juwindar. 2015. Analisis Kesiapan E-Learning Telkom University Dengan Menggunakan E-Learning Readiness (ELR) Model (Studi Kasus ICaring). e-Proceeding of Engineering : Vol.2, No.1 April 2015. ISSN : 2355-9365. Hal. 1184-1188. 
Jurnal Sains Komputer \& Informatika (J-SAKTI)

Volume (2) No.2 September 2018, pp. 191-199

ISSN:2548-9771/EISSN:2549-7200

http://tunasbangsa.ac.id/ejurnal/index.php/jsakti

[6] Seta, Henki Bayu; Theresia Wati dan Nurhafifah Matondang. 2016. Analisis Pengukuran Tingkat Kesiapan Implementasi E-Learning (ELearning Readiness) Studi Kasus : UPN "Veteran" Jakarta. Seminar Nasional Teknologi Informasi dan Multimedia 2016. STMIK AMIKOM Yogyakarta, 6-7 Februari 2016. ISSN : 2302-3805. 2.5-1 - 2.5-6.

[7] Aydın, Cengiz Hakan and Tasci, Deniz. 2005. Measuring Readiness for eLearning: Reflections from an Emerging Country. Educational Technology \& Society, Vol. 8 No. 4. Page. 244-257. 